\title{
Basin-specific effect of global warming on endemic riverine fish in Korea
}

\author{
Namil Chung ${ }^{1,2}$, Yong-Su Kwon ${ }^{2}$, Fengqing Li ${ }^{2}$, Mi-Jung Bae ${ }^{1,3}$, Eu Gene Chung ${ }^{4}$, \\ Kyunghyun Kim ${ }^{4}$, Soon-Jin Hwang ${ }^{5}$ and Young-Seuk Park ${ }^{2,3 *}$ \\ 1 Nakdonggang National Institute of Biological Resources, Sangju, Gyeongsanbuk-do 37242, Republic of Korea \\ 2 Department of Biology, Kyung Hee University, Dongdaemun, Seoul 02447, Republic of Korea \\ 3 Department of Life and Nanopharmaceutical Science, Kyung Hee University, Dongdaemun, Seoul 02447, Republic of Korea \\ 4 National Institute of Environmental Research, Seogu, Incheon 22689, Republic of Korea \\ ${ }^{5}$ Department of Environmental Science, Konkuk University, Gwangjin, Seoul 05029, Republic of Korea
}

Received 2 March 2015; Accepted 24 July 2015

\begin{abstract}
The differences in geographical setting among basins create variation in regional climate and local assemblages. Global warming might induce varying degree of changes in the biodiversity and distribution of freshwater fish through water temperature increase in each basin. We investigated the effect of global warming on the thermal habitat suitability of endemic riverine fish in the basin scale and the relationship between change in species loss rate and altitude within a basin. Surface air temperature projections based on A1B emission scenario were used to estimate water temperatures in the major basins of South Korea in the future decades. The thermal tolerances of 39 endemic fish species were estimated from water temperatures and abundances in the habitats using the weighted average regression model. The minimum water temperature was compared with the maximum thermal tolerances to simulate the change in thermal habitat suitability of each species in a basin. Global warming is expected to drive 2-20 species to the risk of removal at $4.3-35.5 \%$ of their thermal habitats during 2060-2080s. The effect was variable according to the species' thermal tolerances and the level of basin-specific water temperature increase. The correlation between species loss rate and altitude was positive only when the relationship was considered separately for each basin. The results implied that global warming would greatly affect the suitable habitats of endemic fish before 2060s in Korean rivers. It was suggested that the biodiversity conservation efforts needs to incorporate the spatial heterogeneity in thermal regime among the basins.
\end{abstract}

Key words: Endemic fish / global warming / thermal habitat suitability / species distribution / weighted average regression model / basin scale

\section{Introduction}

Global climate change may induce long-term shifts in average weather conditions and great changes in environmental variation (IPCC, 2007). It also provides an important context for current ecological research and raises significant ecological questions. Related to biodiversity and global change, those include how spatial and temporal environmental heterogeneity influences diversity and how fast particular species respond to such change, respectively (Sutherland et al., 2013; Li et al., 2014, 2015).

\footnotetext{
*Corresponding author: parkys@khu.ac.kr
}

Changes in biodiversity in global, regional and local scales have been attributed to global change impacts, including land cover alteration, invasive species and climate change (Pereira et al., 2012), and many recent studies have tried to predict the effect of future climate change on biodiversity (Sala et al., 2000; Parmesan, 2006; Buisson et al., 2013; Domisch et al., 2013). It has been suggested that decrease in global biodiversity in freshwater ecosystems would be greater than the change in terrestrial ecosystems. Ricciardi and Rasmussen (1999) estimated the extinction rates of freshwater fauna, which are five times greater than the rates of terrestrial fauna in North America. The combined effect of climate change and water withdrawal might be expected to induce the extinction risk 
of local freshwater fish species up to $75 \%$ until 2070 s (Xenopoulos et al., 2005).

Water temperature is a main factor in evaluating the potential effects of climate change on river ecosystems (Mohseni and Stefan, 1999), since the thermal regime of rivers takes a crucial role in the overall health of stream ecosystems, including water quality and the distribution of aquatic organisms (Caissie, 2006). Studies have revealed that water temperature increase in rivers is related to air temperature elevation and global warming (Mohseni et al., 1999, 2003; Langan et al., 2001). If the current rate of increase in river temperature is maintained for longer term, this could affect the biodiversity and geographical distribution of freshwater fish (Eaton and Scheller, 1996; Rahel et al., 1996; Mohseni et al., 2003) through decreased dissolved oxygen and/or water quality degradation (Murdoch et al., 2000; Ducharne, 2008). Freshwater fish, as poikilotherms, are highly sensitive to change in water temperature (Magnuson et al., 1979; Welch et al., 2004). It is, therefore, essential to estimate the thermal tolerance limits of the organisms and the potential changes in thermal habitat suitability of each species in a given basin to predict the effect of global warming on the biodiversity conservation of freshwater fish.

The study on the effect of global warming on freshwater ecosystems is not common in East Asian monsoon area (Parmesan, 2006), although a few examples could be found. The second generation of bivoltine dragonflies, which usually hatch in late summer - autumn and emerge in the following spring, may emerge in the autumn due to the faster growth rate with increasing summer and autumn water temperature during the past five decades in Japan (Doi, 2008). It has been suggested that global warming would significantly affect the "inhabiting suitability" of fishes adapted to cold water temperature in Japan (Kojiri et al., 2008). Increasing water temperature in winter induced decreases in macroinvertebrates abundance and diversity in two subtropical streams in Central China ( $\mathrm{Li}$ et al., 2012a, 2012b). The potential impact of global warming on river ecosystems in the Korean Peninsula was expected to induce macroinvertebrate species loss (Kwon et al., 2012; Li et al., 2013, 2014).

Korea has been classified into the group whose incident threat to local biodiversity is relatively high, even without considering the thermal regime changes in freshwater due to global warming (Vörösmarty et al., 2010). Given that global warming would exacerbate the risk of species extinction (Heino et al., 2009; Karl et al., 2009), it is important to evaluate the effect of global warming on fish community quantitatively to facilitate the success of biodiversity conservation efforts in the country (Pereira et al., 2010; Parmesan et al., 2011).

Among the factors influencing water temperature in rivers, topography factors are important (including riparian vegetation, latitude and altitude) because they affect atmospheric conditions which are the most important factors (Caissie, 2006). When predicting the effect of climate change on biodiversity, it is required to consider the hierarchical environmental filters affecting regional and local assemblages in multiple spatial scales (Heino et al., 2009). Basin filter (e.g., vegetation and hydrological regimes) determines the diversity and composition of local assemblages at the lower levels (ecosystem, macro-/ microhabitat) through species traits (Poff, 1997). Difference in geographical setting among basins may create characteristic local climate in each basin (Snelder and Biggs, 2002), resulting in different thermal regime under the effect of global warming. It is expected that basin-specific effect of global warming on water temperature could act as additional "filter" and exert varying extent of warming effect on the distribution of fish in each basin through the thermal habitat suitability of individual species.

The basin-specific warming level combined with species-specific thermal tolerance may induce differential effect of global warming on the distribution of fish species in each basin. Without considering the basin-specific thermal regime in each basin, the effect of warming on a species would be the same for all the basins in the national scale. However, the spatially heterogeneous warming effect would create different distribution pattern of a species among basins. Therefore, we aimed to: (1) evaluate the thermal habitat vulnerability of endemic fish species at the basin scale in the next decades, and (2) project the changes in the effect of global warming on fish habitats across altitude through time.

\section{Materials and methods}

\section{Community data}

Fish community data were obtained from the Water Environment Information System (http://water.nier.go.kr) administered by the National Institute of Environmental Research, Ministry of Environment, Republic of Korea. The Ecosystem Health section of the webpage provides the community data of periphytons, macroinvertebrates and fish as well as the physicochemical environmental data at the sampling sites which were located in the five major river basins in the Southern Korean Peninsula (Bae et al., 2011) (Fig. 1).

The five basins include the Han River (HN), Nakdong River (ND), Geum River (GM), Yeongsan River and Seomjin River (YS) Basins (listed in the order of their sizes). Each basin is comprised of the main river channel, its tributaries and small streams (Lee et al., 2011a). The HN (length, $514 \mathrm{~km}$; drainage area, $26219 \mathrm{~km}^{2}$ ) occupies the central part of the peninsula and reaches from the west coast to the east coast. Two major tributaries of the HN rise in the eastern part of the basin, which includes relatively higher mountainous area, and the main channel runs through the western lowland area. The ND (length, $506 \mathrm{~km}$; drainage area, $23384 \mathrm{~km}^{2}$ ) is located in the southeastern part of the peninsula. The areas of the HN and the ND cover more than $70 \%$ of the total area of South Korea. The GM (length, $401 \mathrm{~km}$; drainage area, $9859 \mathrm{~km}^{2}$ ) and Yeongsan River (length, $115 \mathrm{~km}$; drainage 


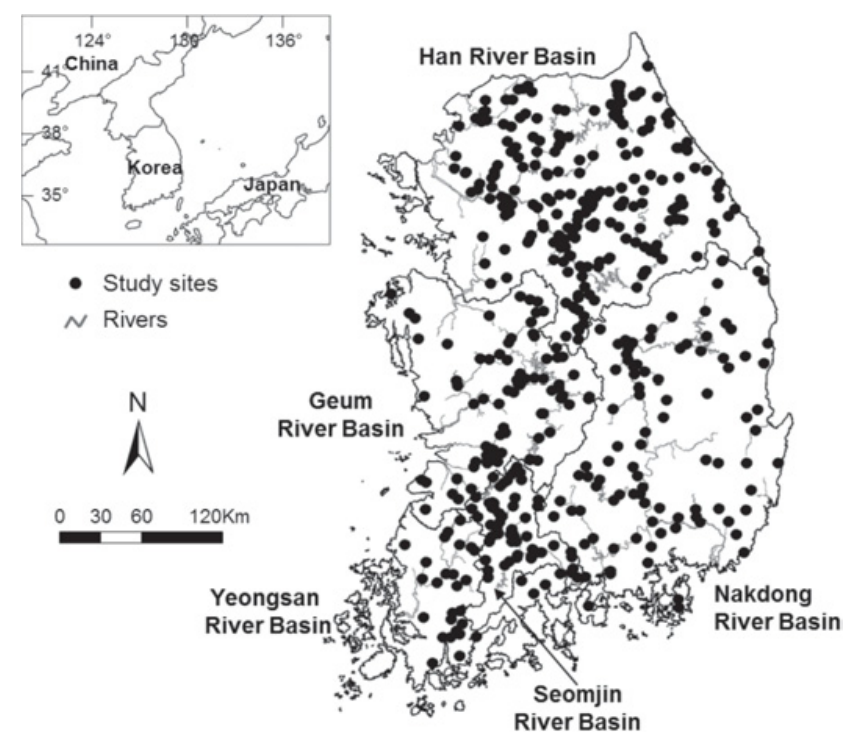

Fig. 1. Locations of the sampling sites in the five major river basins of South Korea.

area, $3371 \mathrm{~km}^{2}$ ) Basins are located in the southwestern part of the peninsula, and the Seomjin River Basin (length, $212 \mathrm{~km}$; drainage area, $4896 \mathrm{~km}^{2}$ ) is in between the ND and Yeongsan River Basins. The YS are usually considered as one river system due to their geographical proximity and relatively smaller sizes compared with the other basins, so that the data from the two basins were combined for the analysis in the basin scale.

The data were surveyed twice a year at each sampling site in spring (April-May) and autumn (SeptemberOctober) in 2009 through the National Aquatic Ecological Monitoring Program (NAEMP) administered by the Ministry of Environment, Republic of Korea. Severe drought (winter to early spring) and flooding season (summer) which often deter proper sampling were avoided in the survey. Fish were collected using kick nets $\left(1.5 \times 0.9 \mathrm{~m}^{2}\right.$ size, $4 \times 4 \mathrm{~mm}^{2}$ mesh $)$ for $30 \mathrm{~min}$ and cast nets $\left(5 \times 5 \mathrm{~mm}^{2}\right.$ mesh) for 20 times per site by well-trained experts following the guideline (MOE/NIER, 2008) in which the details about the sampling procedure can be found. The same method was applied to all the sites to reduce the variation associated with different sampling equipment. The sampling was conducted in a $200 \mathrm{~m}$-long reach including riffle, run and pool zones in each site. All the fish captured were identified to species level in the field (Kim and Park, 2002), counted and released. The individuals whose length were less than $20 \mathrm{~mm}$ were preserved in $10 \%$ formalin and identified in the laboratories (Lee et al., 2011a; Yoon et al., 2011).

Water quality variables measured in the sampling sites were examined to exclude the sites under the effect of anthropogenic pollution and/or extreme environment that could affect the distribution of fish species. It was required to collect the information on the presence of each species in the undisturbed or minimally disturbed condition to know the species' natural thermal profile in its habitats.
The considered criteria included biological oxygen demand $\left(\leq 3 \mathrm{mg} . \mathrm{L}^{-1}\right)$ and dissolved oxygen $\left(\geq 5 \mathrm{mg} . \mathrm{L}^{-1}\right)$ that fulfill the Moderate Level (the fourth among seven levels) of the Water Quality Standard of Rivers and Streams of Korea. The sites having extreme values (greater than upper 95th percentile) of conductivity $\left(>431.65 \mu \mathrm{S} . \mathrm{cm}^{-1}\right)$, total nitrogen $\left(>5.06 \mathrm{mg} . \mathrm{L}^{-1}\right)$ and total phosphorus ( $>0.26 \mathrm{mg} . \mathrm{L}^{-1}$ ) were also deleted from the database. As a result, the data from 478 sites were analyzed.

The fish were categorized into four groups (i.e., lotic, lentic, migratory or alien species) according to their major habitat preferences in the light of the information on species' ecological traits. The information were obtained through literatures (MOE/NIER, 2009; NIBR, 2011) and "Species Korea" database (http://www.nibr.go.kr/ species/) administered by the National Institute of Biological Resources, Ministry of Environment, Republic of Korea. The riverine fish were selected, which mainly inhabit lotic habitats. Continuous water flow and turbulence in rivers may create uniform temperature profile by mixing the water in a stream segment. That makes the fish experience similar water temperature in a habitat at a given time. Such characteristics of flowing water are important in estimating the effect of global warming on the thermal habitat suitability of fish species, because the estimation of potential impact of warming is based on the comparison between thermal tolerances of the species and the minimum water temperature in the basins (see below for detail). Those classified as lentic species inhabiting impounded water (ponds, reservoirs and lakes) were not included in the further analysis. Lentic fish can find alternative thermal habitats in the deeper parts of water body if the surface water temperature is not suitable for survival of the species. That may make it difficult to evaluate the effect of global warming on the presence of fish in a site. Alien and migratory (anadromous, catadromous or diadromous) species were also excluded to avoid the problem of considering the thermal regime of potential habitats of those species out of the peninsula. In total, 39 endemic riverine fish were compiled, including eight endangered and one natural monument species protected by the law (Table 1). The abundance data of each species for the study years in a site were averaged for further analysis.

\section{Temperature data}

The current and future surface air temperature data were obtained from the Climate Change Information Center (CCIC; http://www.climate.go.kr), Korea Meteorological Administration (KMA). The coupled atmosphere-ocean climate model (ECHO-G; Legutke and Voss, 1999) simulated global climate change based on the Special Report on Emission Scenarios (SRES; Nakicenovic et al., 2000), and the results included monthly air temperature estimates whose resolution was $400 \mathrm{~km}$. The global projection, however, was too coarse for Korea 
Table 1. Expected decreases in thermal habitat suitability of 39 endemic riverine fish arranged in ascending order of the maximum thermal tolerance.

\begin{tabular}{|c|c|c|c|c|c|c|c|c|}
\hline \multirow{2}{*}{$\frac{\text { Group }}{\mathrm{I}}$} & \multirow{2}{*}{$\begin{array}{l}\text { Acronym } \\
\text { PSTE }\end{array}$} & \multirow{2}{*}{$\begin{array}{c}\text { Species name } \\
\text { Pseudopungtungia tenuicorpa }\end{array}$} & \multirow{2}{*}{$\begin{array}{l}\text { Number of sites } \\
43\end{array}$} & \multirow{2}{*}{$\begin{array}{l}\text { Remark } \\
\text { E }\end{array}$} & \multicolumn{4}{|c|}{ Basin } \\
\hline & & & & & & \multicolumn{2}{|l|}{$\mathrm{HN}^{\mathrm{a}}$} & \\
\hline & RHKU & Rhynchocypris kumgangensis & 40 & & & \multicolumn{2}{|l|}{$\mathrm{HN}^{\mathrm{a}}$} & \\
\hline & HEMY & Hemibarbus mylodon & 24 & M & & \multicolumn{2}{|l|}{$\mathrm{HN}$} & \\
\hline & MILO & Microphysogobio longidorsalis & 92 & & & \multicolumn{2}{|l|}{$\mathrm{HN}$} & \\
\hline & SIMI & Silurus microdorsalis & 13 & & $\mathrm{GM}^{\mathrm{b}}$ & \multicolumn{2}{|l|}{$\mathrm{HN}$} & \\
\hline & KORO & Koreocobitis rotundicaudata & 114 & & & \multicolumn{2}{|l|}{$\mathrm{HN}$} & \\
\hline & GOBR & Gobiobotia brevibarba & 29 & $\mathrm{E}$ & $\mathrm{GM}^{\mathrm{b}}$ & \multicolumn{2}{|l|}{$\mathrm{HN}$} & \\
\hline & ACSI & Acheilognathus signifer & 29 & $\mathrm{E}$ & & \multicolumn{2}{|l|}{$\mathrm{HN}$} & \\
\hline & LIAN & Liobagrus andersoni & 91 & & & \multicolumn{2}{|l|}{$\mathrm{HN}$} & \\
\hline & IKKO & Iksookimia koreensis & 181 & & $\mathrm{GM}^{\mathrm{a}}$ & \multicolumn{2}{|l|}{$\mathrm{HN}$} & $\mathrm{YS}^{\mathrm{b}}$ \\
\hline \multirow[t]{19}{*}{ II } & COSP & Coreoleuciscus splendidus & 213 & & $\mathrm{GM}^{\mathrm{a}}$ & \multirow[t]{2}{*}{$\mathrm{HN}$} & \multirow[t]{2}{*}{ ND } & $\mathrm{YS}^{\mathrm{b}}$ \\
\hline & PSNI & Pseudopungtungia nigra & 12 & $\mathrm{E}$ & $\mathrm{GM}^{\mathrm{a}}$ & & & \\
\hline & ZAKO & Zacco koreanus & 273 & & $\mathrm{GM}^{\mathrm{a}}$ & \multirow[t]{2}{*}{$\mathrm{HN}$} & \multirow[t]{2}{*}{ ND } & $\mathrm{YS}^{\mathrm{b}}$ \\
\hline & ACSO & Acheilognathus somjinensis & 11 & $\mathrm{E}$ & & & & $\mathrm{YS}^{\mathrm{b}}$ \\
\hline & COPA & Cobitis pacifica & 10 & & & $\mathrm{HN}$ & \multicolumn{2}{|l|}{ ND } \\
\hline & GOMA & Gobiobotia macrocephala & 17 & $\mathrm{E}$ & $\mathrm{GM}^{\mathrm{a}}$ & \multicolumn{3}{|l|}{$\mathrm{HN}$} \\
\hline & ODIN & Odontobutis interrupta & 151 & & $\mathrm{GM}^{\mathrm{a}}$ & \multicolumn{2}{|l|}{$\mathrm{HN}$} & $\mathrm{YS}^{\mathrm{a}}$ \\
\hline & COHE & Coreoperca herzi & 207 & & $\mathrm{GM}^{\mathrm{a}}$ & $\mathrm{HN}$ & ND & $\mathrm{YS}^{\mathrm{a}}$ \\
\hline & MIYA & Microphysogobio yaluensis & 235 & & $\mathrm{GM}^{\mathrm{a}}$ & $\mathrm{HN}$ & ND & $\mathrm{YS}^{\mathrm{a}}$ \\
\hline & NIMU & Niwaella multifasciata & 21 & & & $\mathrm{HN}$ & ND & \\
\hline & ACKO & Acheilognathus koreensis & 67 & & $\mathrm{GM}^{\mathrm{a}}$ & & ND & $\mathrm{YS}^{\mathrm{a}}$ \\
\hline & PSKO & Pseudobagrus koreanus & 84 & & $\mathrm{GM}^{\mathrm{a}}$ & $\mathrm{HN}$ & ND & $\mathrm{YS}^{\mathrm{a}}$ \\
\hline & $\mathrm{ACMJ}$ & Acheilognathus majusculus & 28 & & & & & $\mathrm{YS}^{\mathrm{a}}$ \\
\hline & SANI & Sarcocheilichthys nigripinnis morii & 54 & & $\mathrm{GM}^{\mathrm{a}}$ & $\mathrm{HN}$ & ND & $\mathrm{YS}^{\mathrm{a}}$ \\
\hline & ABSP & Abbottina springeri & 20 & & GM & $\mathrm{HN}$ & & $\mathrm{YS}^{\mathrm{a}}$ \\
\hline & LIME & Liobagrus mediadiposalis & 34 & & GM & $\mathrm{HN}$ & ND & $\mathrm{YS}^{\mathrm{a}}$ \\
\hline & SAVA & Sarcocheilichthys variegatus wakiyae & 75 & & GM & $\mathrm{HN}$ & ND & $\mathrm{YS}^{\mathrm{a}}$ \\
\hline & COTE & Cobitis tetralineata & 38 & & & & ND & $\mathrm{YS}^{\mathrm{a}}$ \\
\hline & COHA & Cobitis hankugensis & 38 & & & & ND & \\
\hline III & ODPL & Odontobutis platycephala & 173 & & GM & $\mathrm{HN}$ & ND & $\mathrm{YS}^{\mathrm{a}}$ \\
\hline & SQGR & Squalidus gracilis majimae & 218 & & GM & $\mathrm{HN}$ & ND & $Y^{\mathrm{a}}$ \\
\hline & HEEI & Hemiculter eigenmanni & 33 & & GM & $\mathrm{HN}$ & ND & $\mathrm{YS}^{\mathrm{a}}$ \\
\hline & IKLO & Iksookimia longicorpa & 30 & & GM & & ND & $Y^{\mathrm{a}}$ \\
\hline & RHUY & Rhodeus uyekii & 87 & & GM & $\mathrm{HN}$ & ND & $\mathrm{YS}^{\mathrm{a}}$ \\
\hline & GONA & Gobiobotia nakdongensis & 16 & $\mathrm{E}$ & & & ND & \\
\hline & IKHU & Iksookimia hugowolfeldi & 16 & & & & ND & YS \\
\hline & SQMU & Squalidus multimaculatus & 11 & & & & ND & \\
\hline & KONA & Koreocobitis naktongensis & 9 & $\mathrm{E}$ & & & ND & \\
\hline & MIJE & Microphysogobio jeoni & 8 & & GM & $\mathrm{HN}$ & & \\
\hline
\end{tabular}

$E$, endangered species; $M$, natural monument species; $G M$, Geum River Basin; $H N$, Han River Basin; $N D$, Nakdong River Basin; $Y S$, Yeongsan River and Seomjin River Basins.

a Decrease in thermal habitat suitability was expected in 2080s only.

${ }^{b}$ Decrease in thermal habitat suitability was expected in both 2060 s and 2080s.

since a couple of grids were enough to cover the Southern Korean Peninsula. To overcome this limitation and add details to the global model, the Fifth Generation Penn State/NCAR Mesoscale Model (MM5; Grell et al., 1994) simulated regional climate change based on A1B emission scenario (up to $720 \mathrm{ppm} \mathrm{CO}_{2}$ in 2100) which is one of the SRES scenarios. The MM5 model produced high-resolution (27 km scale) climate change data including monthly air temperature estimates. The results of regional climate model were further downscaled statistically to generate the Applied Climate Data in Korea for the application of climate change scenario to agricultural study. The resolution of the Applied Climate Data was $30 \mathrm{~m}$ for the monthly air temperate estimates.
The CCIC provided the maximum and minimum air temperature data as monthly averages for every 10 years from 2000 to 2100 . The air temperature data were extracted from nine grid cells (cell size: $30 \times 30 \mathrm{~m}^{2}$ ) for each of 478 sites for fish community survey described above using ArcMap 9 (ESRI, 2004). Each set of nine grid cells were composed of a center cell including the ordination of sampling site plus surrounding eight cells. The data extracted for a site were averaged for the decade to give the mean value as current surface air temperature in each site.

Additional sets of data were extracted to give the minimum mean air temperature in each basin for the future decades. The river buffer zones were set as 
$200 \mathrm{~m}$-wide areas in both sides along the central axis of entire river channels. The data of all the grid cells included in the buffer zones of the basins were extracted and averaged for each decade. All the mean values for each basin were combined, and the lower 1st percentile was set as the minimum mean air temperature of the basin for the decades of 2020s, 2040s, 2060s and 2080s.

The water temperature was estimated from air temperature using the linear regression equation proposed by Morrill et al. (2005):

$$
T_{\mathrm{w}}=2.56+0.71 T_{\mathrm{A}}
$$

where $T_{\mathrm{w}}$ and $T_{\mathrm{A}}$ are water and air temperatures, respectively. The equation was based on the data from 43 rivers in 13 countries. The temperature measurements included weekly to monthly instantaneous surface water temperature and weekly mean air temperature from January 1, 1996 to August 31, 2001.

\section{Thermal tolerances of fish}

The weighted average regression (WAR) model (ter Braak and van Dam 1989; ter Braak and Juggins, 1993) was applied to estimate the thermal profiles of the fish using C2 Version 1.6.6 (Juggins, 2007). The WAR model is based on the idea that a species will be most abundant in the sites having the best environmental gradient (optimum) for the species and that the species cannot survive when the value is too low or too high (tolerance). The model estimated the optimum water temperature of a species as a weighted average $(W A)$ and the tolerance of the species as a weighted standard deviation $(T O L)$ :

$$
\begin{gathered}
W A=\frac{\sum_{i=1}^{n} x_{i} \times y_{i j}}{\sum_{i=1}^{n} y_{i j}} \\
T O L=\sqrt[2]{\frac{\sum_{i=1}^{n}\left(x_{i}-W A\right)^{2} \times y_{i j}}{\sum_{i=1}^{n} Y_{i j}}}
\end{gathered}
$$

where $x_{i}$ is water temperature at site $i$, and $y_{i j}$ is the abundance of species $j$ in site $i$. The maximum thermal tolerance (Max_Tol) of a species was estimated as the sum of $W A$ and $T O \bar{L}$.

The 39 species were divided into three groups based on the percentile of Max_Tol. The fish whose maximum thermal tolerances were lower than 25th percentile were classified into Group I. Group II included the species having Max_Tol values ranging 25th-75th percentiles, and Group III included the species having Max_Tol values greater than 75 th percentile (Table 1).

\section{Thermal habitat suitability}

The maximum thermal tolerances of fish were compared with the minimum water temperature estimate in each basin. If the Max_Tol of a species was lower than the minimum water temperature in a basin in a given future decade, it was assumed that the species cannot survive in the basin due to the lack of its suitable thermal habitats under the effect of global warming. The changes in thermal habitat suitability of a species were determined by counting the number of sites whose thermal regime was not suitable to the species in each basin. The values were summarized to give the ratio of fish species which the amount of suitable thermal habitat (i.e., sampling site) decreased under the effect of global warming. The number of fish species which lost its thermal suitability in a site was counted as well to know the ratio of thermal habitat affected by increasing water temperature in each basin.

\section{Statistical analysis}

The analysis of variance (ANOVA) was applied to test the differences in optimum water temperature and maximum thermal tolerance among three groups (see Thermal tolerances of fish for detail), and the changes in thermal habitat suitability in terms of the number of sites and species among the basins. A Tukey's multiple comparisons test was followed, if the differences in ANOVA test were significant $(P<0.05)$. The simple linear correlation was applied to analyze the relationship between the changes in thermal habitat suitability of fish species and the maximum thermal tolerance (for each group) or altitude (for each basin). All statistical analyses were done with SPSS Version 20 (IBM, 2011).

\section{Results}

\section{Minimum water temperature in the basins}

The minimum water temperature estimates in each basin showed a consistently increasing pattern. The values were the lowest in $\mathrm{HN}$ and the greatest in YS in every decade, ranging from $7.82^{\circ} \mathrm{C}$ in $\mathrm{HN}(2020 \mathrm{~s})$ to $12.19^{\circ} \mathrm{C}$ in YS (2080s) (Fig. 2). The differences in the minimum water temperatures between adjacent two decades in a basin were similar among the basins except between 2000s and 2020s. The differences in the minimum water temperatures among the basins in a decade were relatively consistent through the study period.

\section{Thermal profiles of endemic fish}

The optimum water temperature of 39 fish species ranged $8.75-11.86^{\circ} \mathrm{C}$, and the maximum thermal tolerances ranged $9.80-12.46^{\circ} \mathrm{C}$ (Fig. 3). According to the ascending order of maximum thermal tolerance, 39 species were classified into three groups (Table 1). The optimum water temperature was significantly different among three groups $\left(F_{2,36}=88.74, P<0.001\right)$, which was the greatest in group III $\left(11.51 \pm 0.06^{\circ} \mathrm{C}\right)$, followed by group II $\left(10.88 \pm 0.08^{\circ} \mathrm{C}\right)$ and Group I $\left(9.50 \pm 0.15^{\circ} \mathrm{C}\right.$; Fig. 4(a)). 


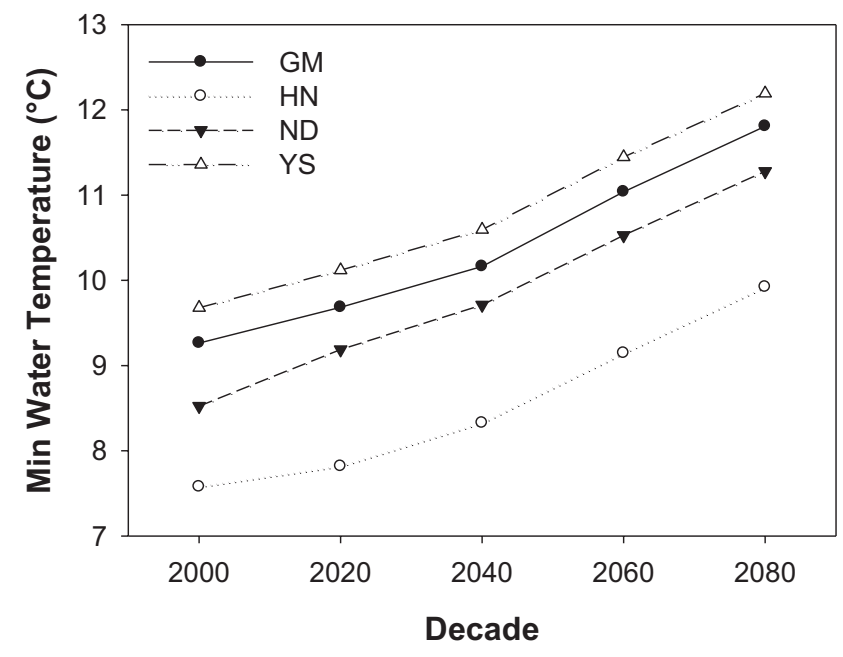

Fig. 2. The minimum average water temperature in each basin for the decades with 20 years intervals. Abbreviations for the names of basins are the same as in Table 1.

The Max_Tol value of group III $\left(12.19 \pm 0.06^{\circ} \mathrm{C}\right)$ was significantly greater $\left(F_{2,36}=88.15, P<0.001\right)$ than those of groups II $\left(11.63 \pm 0.05^{\circ} \mathrm{C}\right)$ and I $\left(10.43 \pm 0.15^{\circ} \mathrm{C}\right.$; Fig. 4(b)).

Group I included ten species, and their Max_Tol values ranged $9.80-11.19^{\circ} \mathrm{C}$. Nineteen species were classified into group II (Max_Tol: $11.30-11.94^{\circ} \mathrm{C}$ ) and ten species into group III (Max_Tol 11.97-12.46 ${ }^{\circ} \mathrm{C}$ ). The order of species in terms of the optimum water temperature was similar to that of the maximum thermal tolerances in group I. Only six among ten species had similar species order of optimum temperature and maximum tolerance values in group III. In Group II, the order of species was different between optimum temperature and Max_Tol (Table 1; Fig. 3).

\section{Changes in thermal habitat suitability of endemic fish}

The thermal habitat suitability of the 39 fish species did not change within 2040 s with $0.90-1.19^{\circ} \mathrm{C}$ increases in the minimum water temperature (Figs. 2 and 4(c)). The increasing minimum water temperature ranging $1.57-$ $2.00{ }^{\circ} \mathrm{C}$ compared to 2000 s, which affected six species in the groups I and II, resulted in lower thermal habitat suitability by $4.3 \%$ on average in 2060 s for the 39 endemic fish species. Three species (Silurus microdorsalis, Gobiobotia brevibarba and Iksookimia koreensis) in group I were affected by increasing water temperature in 2060s, resulting in the decrease in the proportion of suitable thermal habitats by $2.97 \%$ on average. Three species (Coreoleuciscus splendidus, Zacco koreanus and Acheilognathus somjinensis) in group II also exhibited lower thermal habitat suitability by $7.17 \%$ on average in 2060s. One endangered species ( $A$. somjinensis) was expected to be completely removed from YS, which is only found in the basin (Table 1). None of the species in group III showed changes in thermal habitat suitability under the effect of global warming in 2060s. The differences in average changes in thermal habitat among three groups were not statistically significant in 2060 s $\left(F_{2,36}=0.64, P=0.53\right.$; Fig. $\left.4(\mathrm{c})\right)$.

The thermal habitat suitability of the 39 endemic fish species were expected to decrease by $35.5 \%$ on average in 2080s with $2.34-2.75^{\circ} \mathrm{C}$ increases in the minimum water temperature compared to 2000 s, which affected 26 species in the groups I, II and III (Figs. 2 and 4c). Five species (Pseudopungtungia tenuicorpa, Rhynchocypris kumgangensis, S. microdorsalis, G. brevibarba and I. koreensis) in Group I were expected to be affected $(25.13 \%$ decrease on average) by the increasing water temperature, and two of them ( $P$. tenuicorpa and $R$. kumgangensis) were likely to experience $100 \%$ thermal habitat removal in $\mathrm{HN}$. Both of the species were observed in $\mathrm{HN}$ only, and

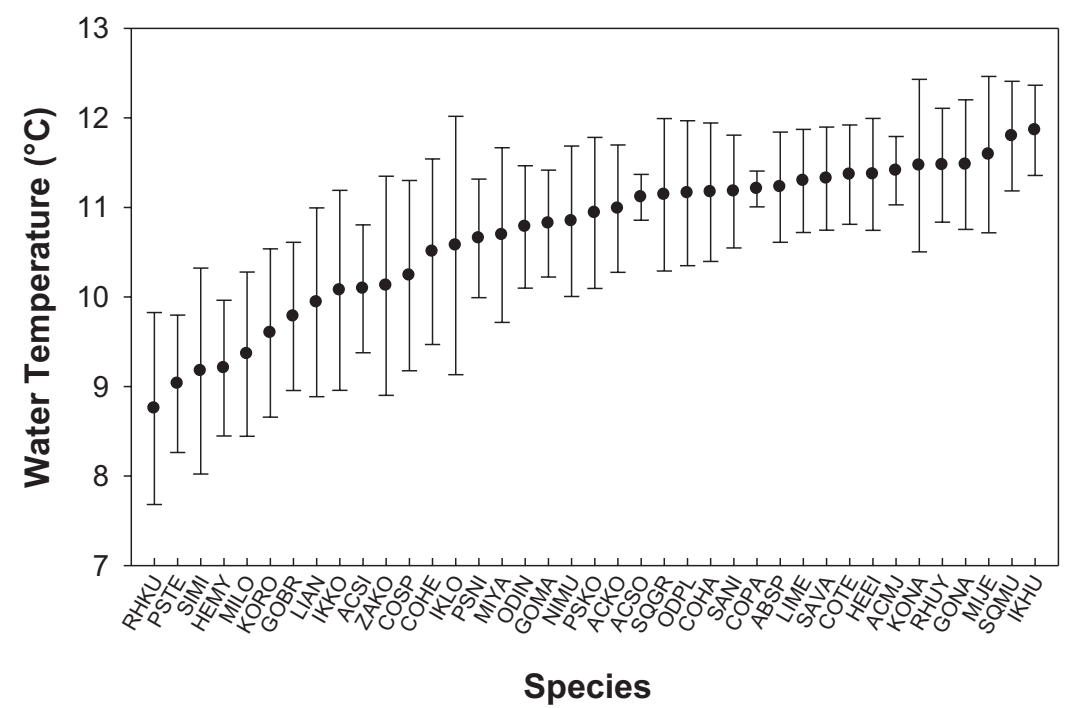

Fig. 3. The optimum $(\bullet)$ and tolerance (error bars) water temperature for 39 endemic riverine fish. The upper ends of error bars indicate the maximum thermal tolerances of the species. Refer to Table 1 for the acronyms of species name. 

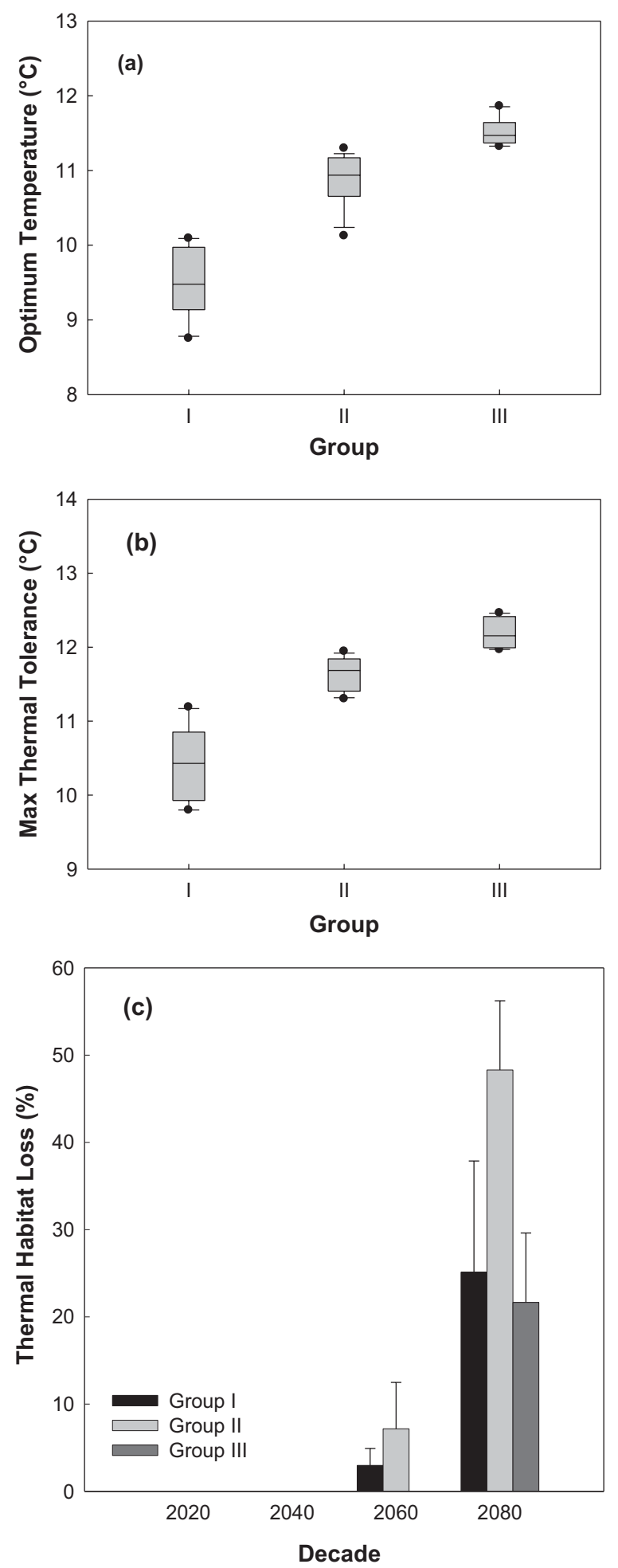

Fig. 4. The optimum water temperature (a) and maximum thermal tolerance (b) of the riverine fish classified into three groups. The Tukey's multiple comparisons tests indicated that all three groups of fish differed significantly $(P<0.05)$ in the optimum water temperature and maximum thermal tolerance. The cross line inside the boxplot indicates the median, and the bottom and top of the box are the first and third quartiles, respectively. The lower and upper whiskers represent the data within 1.5 interquartile range. The outliers were marked with
$P$. tenuicorpa was classified as an endangered species (Table 1; Fig. 4(c)). Sixteen species in Group II showed decrease in thermal habitat suitability by $48.29 \%$ on average in 2080s. Three species (Pseudopungtungia nigra, A. somjinensis and Cobitis tetralineata) in Group II were observed in GM or YS only, and they were expected to experience $100 \%$ thermal habitat removal. Two ( $P$. nigra and A. somjinensis) of them were classified as endangered species. Three species (Cobitis pacifica, Niwaella multifasciata and Cobitis hankugensis) in Group II exhibited no change in thermal habitat suitability. Five species (Odontobutis platycephala, Squalidus gracilis majimae, Hemiculter eigenmanni, Iksookimia longicorpa and Rhodeus uyekii) in Group III showed decrease in thermal habitat suitability in 2080s (21.65\% on average), and the other five species showed no change. The differences in average changes in thermal habitat suitability of the fish species were marginally significant among three groups in 2080s $\left(F_{2,36}=2.63\right.$, $P=0.09$; Fig. 4(c)).

The simple linear correlation between the maximum thermal tolerance and the changes in thermal habitat suitability of 39 species in each group was statistically significant only for group III in 2080s $(P<0.01$; Fig. 5). The relationship was marginally significant for group II in 2060s and group I in 2080s. The correlation was insignificant not only for group I in 2060s and group II in 2080s, but also for all 39 species in both decades.

\section{Changes in distribution of endemic fish in each basin}

The effect of global warming on the riverine endemic fish communities was the greatest in YS followed by GM, $\mathrm{HN}$ and ND in 2060s $\left(F_{3,474}=122, P<0.001\right)$ and $2080 \mathrm{~s}$ $\left(F_{3,474}=1116, P<0.001\right)$ in terms of basin-specific species removal (Fig. 6). Two species (S. microdorsalis and $G$. brevibarba) at six sites in GM and four species (I. koreensis, C. splendidus, Z. koreanus and A. somjinensis) at 53 sites in YS could be at risk of removal from their thermal habitats by elevating water temperature within 2060s. No species would be affected by increasing water temperature in HN and ND within 2060s. The percentage of endemic species losing thermal habitat suitability at each site in YS $(13.4 \%)$ was significantly greater than those in GM $(0.85 \%), \mathrm{HN}$ and ND $(P<0.001)$, but the differences were not statistically significant among GM, $\mathrm{HN}$ and ND in 2060s $(P=0.74)$.

points $(\bullet)$. Percentage of thermal habitat loss of 39 endemic riverine fish classified into three groups in each decade under the effect of global warming (c). Error bars indicate standard deviation. None of the species was expected to be affected by increasing water temperature due to global warming during 2020s-2040s. 

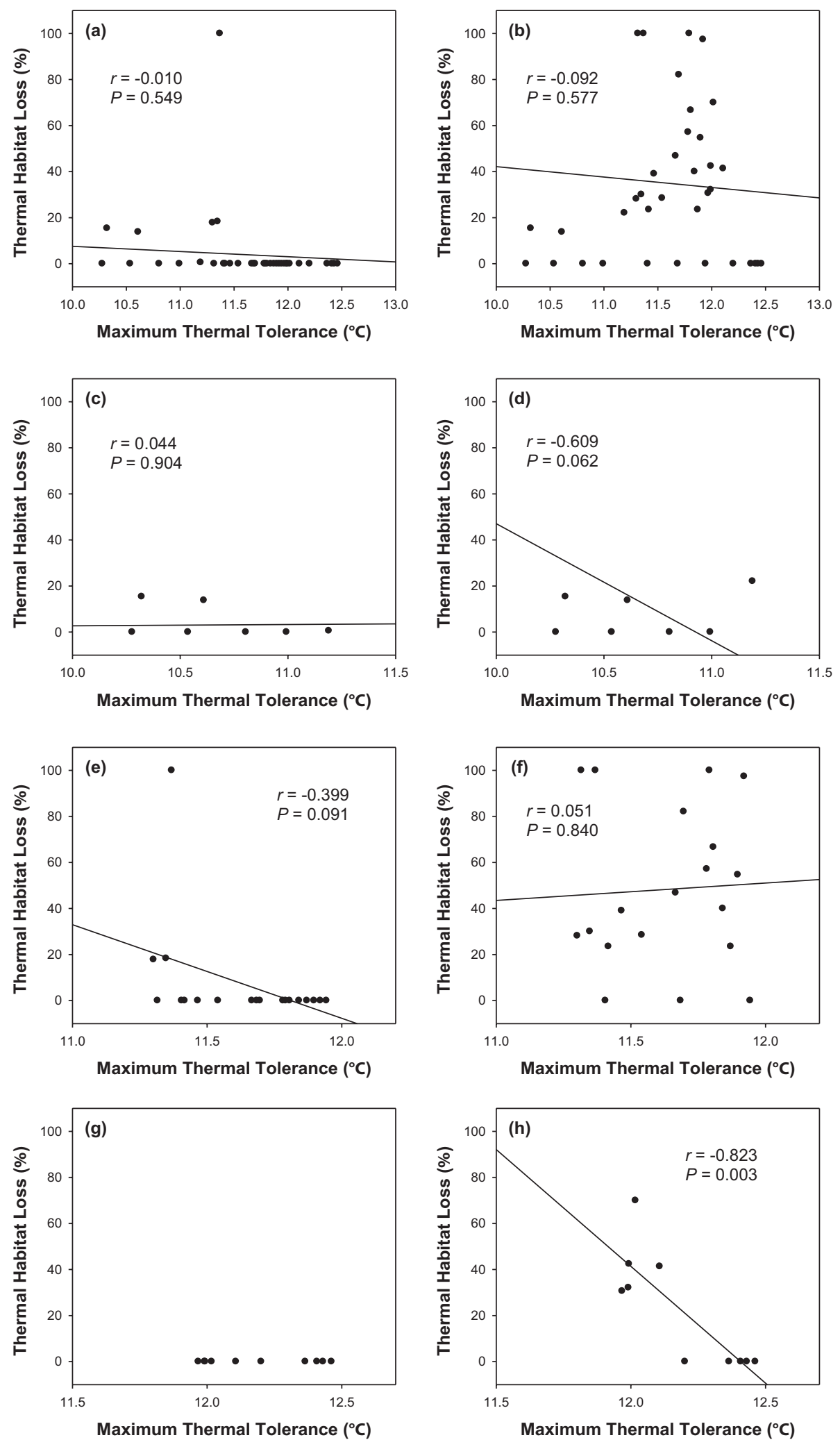

Fig. 5. The relationship between changes in thermal habitat suitability and the maximum thermal tolerance of all 39 species (a,b) as well as the species in the groups I (c,d), II (e,f) and III (g,h) in 2060s (left panel) and 2080s (right panel). Correlation coefficient could not be calculated for group III in 2060s (g), since there was no change in the thermal habitat suitability for the species in the group within the decade. 

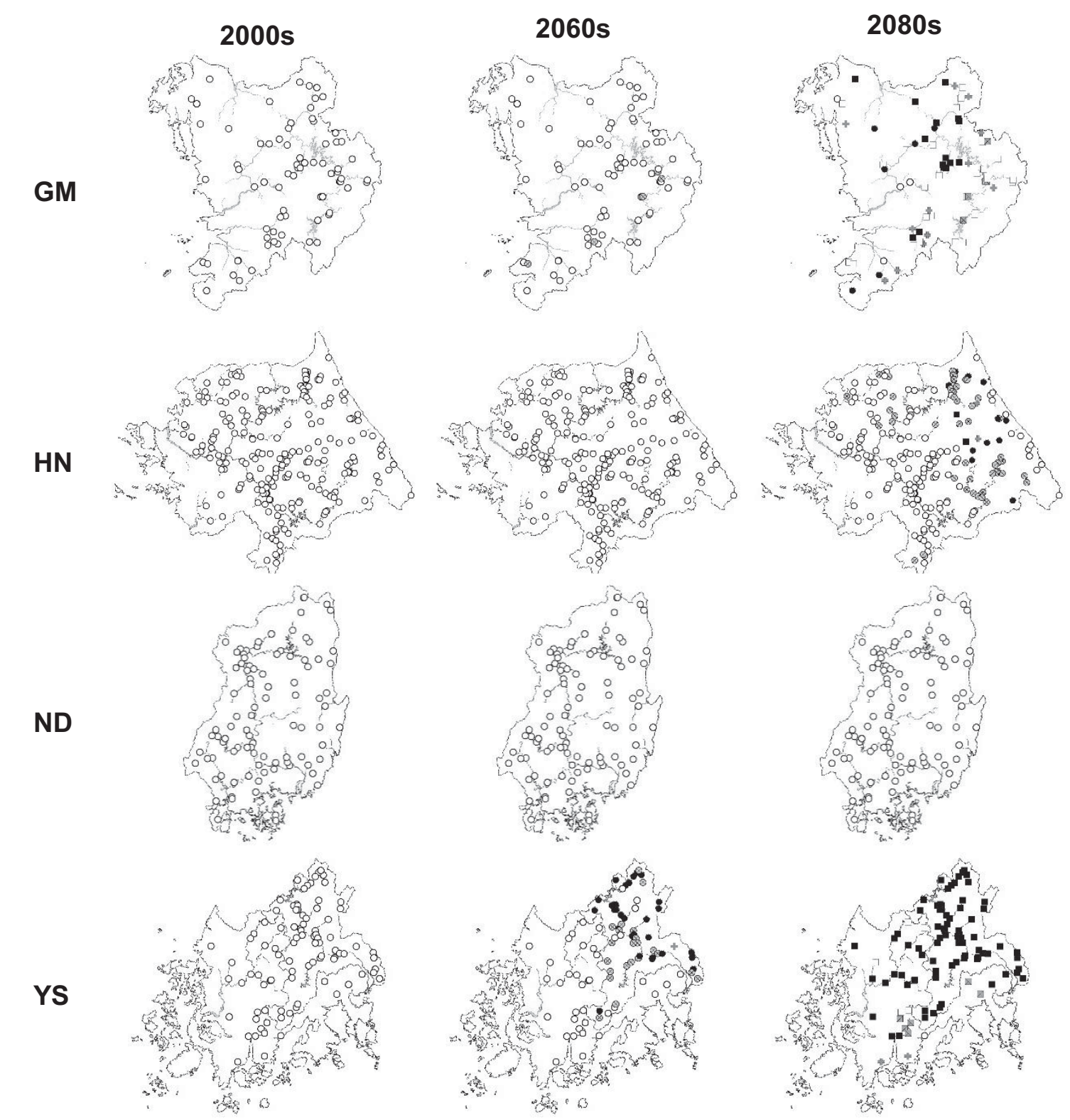

\section{$\circ 0 \% \otimes 1-20 \% \bullet 21-40 \% \bowtie 41-60 \% \square 61-80 \% \otimes 81-99 \% \square 100 \%$}

Fig. 6. Basin-specific changes in percent endemic fish losing thermal habitat suitability under the effect of global warming at each site during 2060s and 2080s. Zero percent indicates no specie removal from a site, and 100\% does all species removal from a site. Abbreviations for the names of basins are the same as in Table 1.

Greater number of species exhibited lower thermal habitat suitability at sites in each basin in 2080s than 2060s due to increasing water temperature except ND (Fig. 6). Thirteen species were expected to lose their thermal habitat suitability at 70 sites in GM within 2080s. Two species (P. tenuicorpa and R. kumgangensis) at 69 sites in $\mathrm{HN}$ and 20 species at 92 sites in YS might be vulnerable to increasing water temperature in 2080s. No species would be at risk of removal in ND in 2080s. The percent species losing thermal habitat suitability at each site would be the greatest in YS $(95.5 \%)$ followed by GM $(67.6 \%)$ and $\mathrm{HN}$ $(6.0 \%)$ in $2080 \mathrm{~s}(P<0.01)$.

\section{Relationship between change in species loss rate and altitude}

The endemic fish's thermal habitats in higher altitude would be significantly more vulnerable to global warming than those in lower altitude for YS in 2060s and for HN in 2080s $(P<0.001 ;$ Fig. 7$)$. When the thermal habitats in the basins were considered altogether, the correlation analysis revealed higher percentage of species removal from the habitats in lower altitude in 2080s mainly due to relatively higher species removal from thermal habitats below $100 \mathrm{~m}$ a.s.l. If each basin, however, examined separately, more 

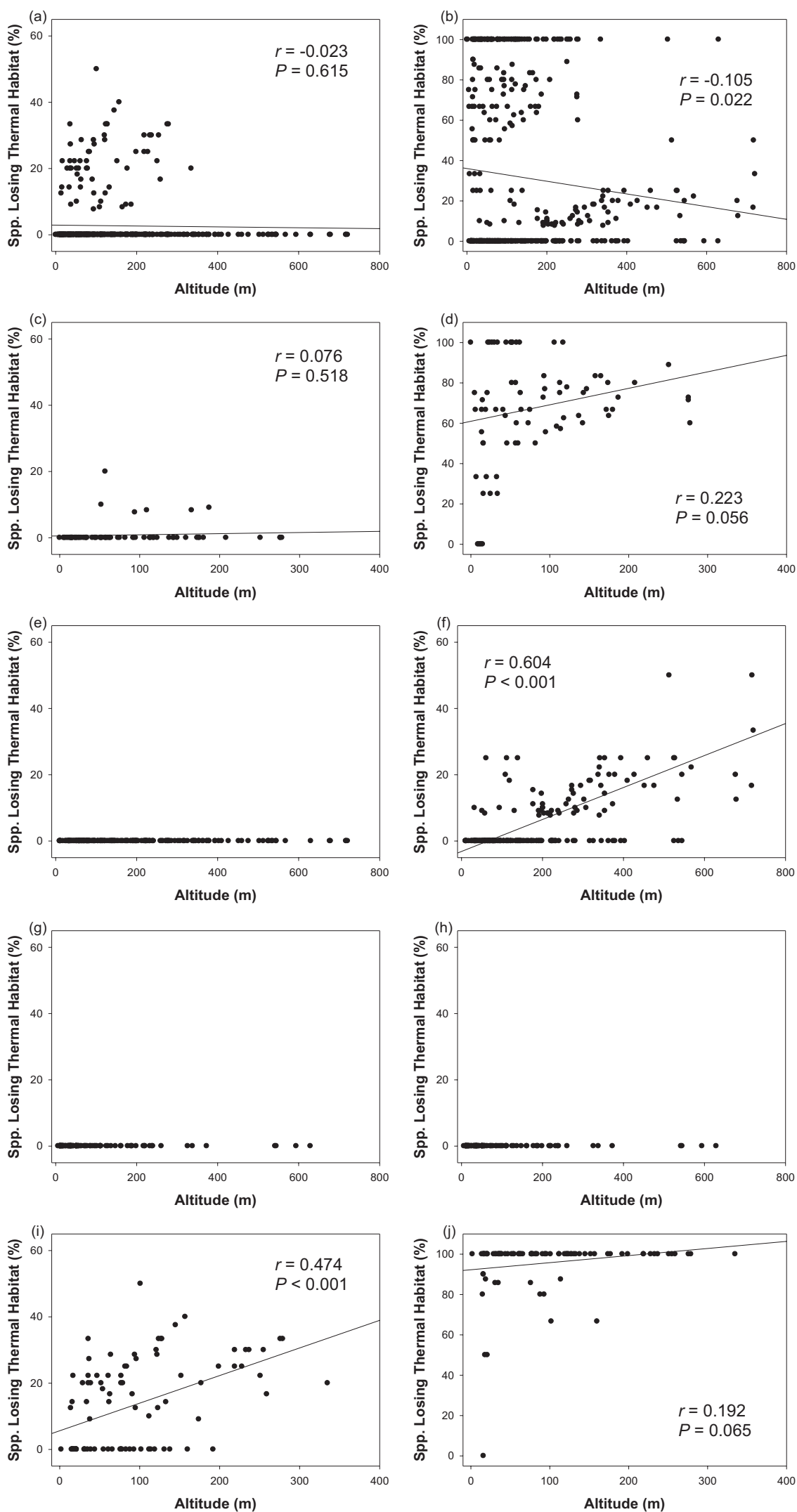

Fig. 7. The relationship between the percentage of species losing thermal suitability and altitude in the sites of whole (a,b), GM (c,d), HN (e,f), ND (g,h) and YS (i,j) in 2060s (left panel) and 2080s (right panel). Correlation coefficients could not be calculated for HN in 2060s (e) and for ND in 2060s (g) and 2080s (h), since the thermal habitat suitability in the basins did not change for the decades. Note the adjusted scales on both axes in each basin. Abbreviations for the names of basins are the same as in Table 1. 

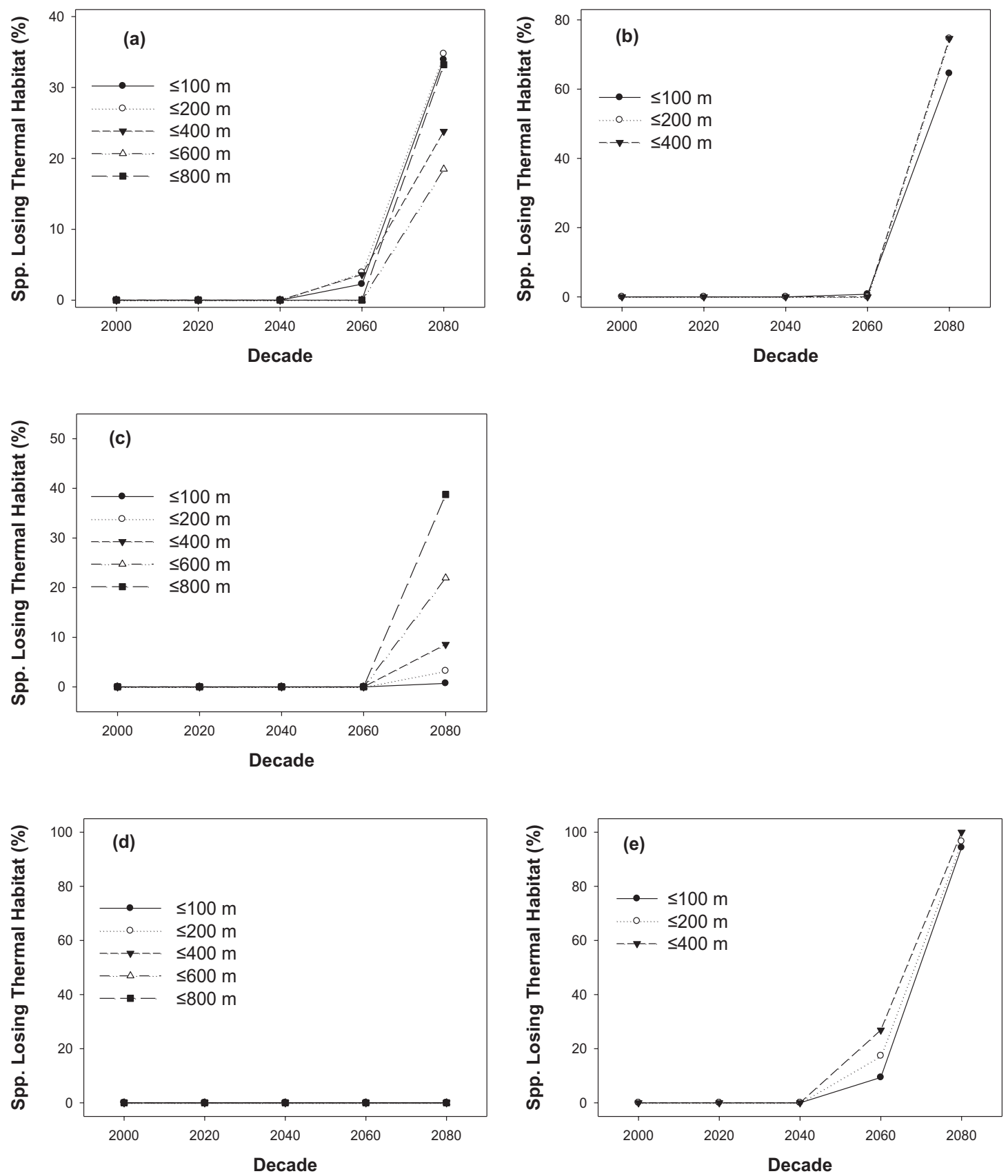

Fig. 8. Changes in the percentage of species losing thermal habitat suitability according to altitude through time in whole (a), GM (b), HN (c), ND (d) and YS (e). Abbreviations for the names of basins are the same as in Table 1. Note the adjusted scale on the $y$-axis in each basin to depict more clearly the difference among sites classified into altitude groups.

species removal was expected in thermal habitats in higher altitudes, except GM in 2060s (Figs. 7 and 8). The pattern was marginally significant for GM and YS in 2080s.

\section{Discussion}

\section{Differential impact of global warming on thermal suitability}

This study suggested that the thermal habitat suitability of South Korean endemic freshwater fish under the effect of global warming would vary with both the maximum thermal tolerance of each species and the level of water temperature increase in each basin. The species having lower Max_Tol values appeared to be more vulnerable to increasing water temperature due to global warming than those having relatively higher Max_Tol within a basin. Such an effect, however, was not consistent among the four basins. The change in thermal habitat suitability of the endemic fish found in multiple basins followed the order of the minimum water temperature of the basins ( $\mathrm{YS}>\mathrm{GM}>\mathrm{ND}>\mathrm{HN}$ ) in both 2060s and 2080s. The difference in thermal habitat suitability change 
among the basins was mainly due to the lower minimum water temperature estimates in HN and ND than those in GM and YS. In addition, the minimum water temperature elevation in $\mathrm{HN}$ and ND did not exceed the maximum thermal tolerance of the fish found in those basins, except $P$. temuicorpa and R. kumgangensis (only found in HN) whose Max_Tol values were the lowest among 39 endemic fish (Figs. 2 and 3). The combined effect of relatively lower minimum water temperature and higher Max_Tol on thermal habitat suitability was conspicuous in ND. The minimum water temperature in ND was lower than in GM by only $0.53{ }^{\circ} \mathrm{C}$, but all the species inhabiting the basin were classified into Groups II (medium temperature-adapted) and III (high temperatureadapted), resulting in no apparent effect of global warming on the thermal habitat suitability of the species in ND.

The differential effect of global warming on the thermal habitat suitability of endemic riverine fish among the basins could be partly attributed to spatial heterogeneity in local climate. Such spatial heterogeneity generates basin-specific thermal regimes which resulted in the variation in surface temperature among the basins. The factors influencing river water temperature can be categorized into four groups including atmospheric conditions, topography, river discharge and streambed. The atmospheric conditions (solar radiation, air temperature, wind speed, evaporation, etc.) are the most important among the factors and are affected by topography or geographical settings (upland shading, riparian vegetation, latitude/altitude, etc.) (Caissie, 2006). The major basins in Southern Korean Peninsula have distinct characteristics including basin area, altitude and land cover type (Hwang et al., 2011) as well as vegetation type (Kim, 2000; Kong, 2004). The differences in riparian vegetation and altitude would affect the stream water temperature through variable atmospheric conditions in each basin, which create variation in thermal regime among the basins. Differences in catchment area and land use type also could contribute to thermal heterogeneity in water temperature at basin or regional scale (Moore, 2006; Scott et al., 2007; Webb et al., 2008).

\section{Potential impact of global warming on thermal habitats in different altitude}

It has been suggested that the habitats of fish inhabiting cold-water ecosystems and high alpine areas would experience the most negative impact of global warming (Cohen et al., 2001), since global warming could affect the distribution and population of freshwater fish through direct effects of elevating water temperature (Field et al., 2007). The distribution of cold-water habitats for riverine fish is limited mainly to mountainous areas in the Southern Korean Peninsula. The species observed in the habitats in higher altitude, therefore, would show greater loss of thermal habitat suitability than the species in lower altitude. However, the expected pattern of ascending order of percentage fish losing thermal habitat suitability with elevating altitude was not observed when the changes in thermal habitat suitability in the habitats of the major basins were considered altogether. The values were the greatest in the sites located in 1-200 m, which were similar those of the sites in $601-800 \mathrm{~m}$. The values were intermediate in the sites located in $201-400 \mathrm{~m}$ and the lowest in the sites located in $401-600 \mathrm{~m}$ in $2080 \mathrm{~s}$. That resulted in a negative relationship between changes in thermal habitat suitability and altitude (Figs. 7(a), (b) and 8(a)).

The expected pattern was apparent, exhibiting greater loss of thermal habitat suitability of fish in the habitats in higher altitude, when the relationship between basinspecific changes in thermal habitat suitability and altitude was considered within a basin separately. The result also proves the differential effect of global warming on the endemic fish in each basin. The pattern of the change in percentage of species losing its thermal suitability according to altitude was similar among the basins: greater in the sites located in higher altitude for YS in 2060s as well as GM, HN and YS in 2080s. The degree of the change in thermal habitat suitability, however, was variable among the basin. The change was the greatest in YS followed by GM and HN, and the order was the same with that of the minimum temperature of the basins except ND. The correlation between thermal habitat suitability and altitude was positive in each basin (Fig. 7). Compared to HN, the changes in thermal habitat suitability were similar among the sites classified into altitude groups 1-100, 101200 and $201-400 \mathrm{~m}$ in GM (2060s and 2080s) and YS (2080s). This may contribute to the negative correlation between thermal habitat suitability change and altitude for the sites of all the basins.

\section{Implications for biodiversity conservation of endangered species}

It is likely that the effect of global warming coupled with anthropogenic habitat disturbances would reduce suitable habitats of some endangered species to a great extent in the major river basins in Korea. Two species, for example, $P$. tenuicorpa and $R$. kumgangensis, mainly found in cool and rapidly flowing small streams, in HN were expected to exhibit lower thermal habitat suitability due to global warming in spite of the lowest water temperature increase estimates (Fig. 6). The expected decline in suitable thermal habitats of the cold-water adapted species supports our first hypothesis and which is closely related to global warming inducing water temperature increase (Eaton and Scheller, 1996; Cohen et al., 2001; Mohseni et al., 2003; Ficke et al., 2007). Previous studies based on simulations predicted negative effect of global warming on the thermal habitats of salmonids and trouts which are vulnerable to increasing water temperature (Lehtonen, 1996; O'Neal, 2002; Rieman et al., 2007). 
The natural habitats of two species above have been declining due to river improvement, water pollution and increasing water temperature coupled with riparian vegetation removal (MOE/NIER, 2009; NIBR, 2011) even without considering the effect of global warming. $P$. tenuicorpa is protected by the law as an endangered species in Korea and has been classified as a Near Threatened species based on revised criteria of the local red list which were originally proposed by the International Union for Conservation of Nature (IUCN). Rhynchocypris kumgangensis has been classified as a Least Concern species by the revised local red list criteria (NIBR, 2011). Although both species has not been considered as threatened species based on the IUCN criteria, the synergistic effect of increasing water temperature due to global warming and human activities would accelerate the reduction of suitable habitats of $P$. tenuicorpa and $R$. kumgangensis in $\mathrm{HN}$.

Another two endangered species would follow the same trend with the species above. Both of P. nigra and $A$. somjinensis have been classified in the category of Endangered species based on the IUCN criteria and are protected by the Korean government. Their distribution in the Southern Korean Peninsula has been declining due to channel improvement, dredging and pollution, resulting in quite limited distribution in the small areas of GM and YS, respectively (NIBR, 2011). The results imply that the latter two endangered species are also highly expected to experience greater rate of suitable habitat reduction which could drive the species into extinction risk in the regions with the combined effects of global warming and anthropogenic stressors.

The difference in basin-specific temperature increase suggests the application of differentiated conservation and recovery efforts for the species having higher maximum tolerance and inhabiting in the basin with lower water temperature increase estimate. Another two endangered species, for example, Gobiobotia nakdongensis and Koreocobitis naktongensis have been classified as a vulnerable species and an endangered species based on the IUCN criteria, respectively (NIBR, 2001). The distributions of both species are limited to ND, and they have quite small number of suitable habitats. The results indicated that decrease in the suitable habitats of the species would be resulted from water pollution, channel improvement and dam construction (NIBR, 2001) rather than global warming. That is mainly because of the lower temperature increase estimates in ND under the effect of global warming, which does not exceed the species' relatively higher maximum thermal tolerances (Table 1, Fig. 6).

\section{Factors affecting the distribution of fish}

This study considered only water temperature that can influence the distribution of freshwater fish in the rivers to simulate thermal habitat suitability. The distribution of fish in Korean rivers are constrained by several factors
(Bae et al., 2011; Yoon et al., 2011; Kwon et al., 2012) including altitude, stream order, slope, water quality and substrate size, etc. Among the factors, altitude had the strongest correlation with species distribution of freshwater fish in the major rivers of Korea (Yoon et al., 2011), confirms our third hypothesis and was highly correlated with water temperature (Walling and Webb, 1994). We regarded, hence, water temperature as the most relevant factor to estimate the changes in species distribution of riverine fish under the effect of global warming when the other factors would not change.

Including additional metrics of factors such as water quality degradation, hydrological change and biological interaction could more precisely simulate the effect of global warming (or climate change) on the distribution of riverine fish (Chu et al., 2005). It has been suggested that the combined effect of chemical pollution and physical habitat modification would modify fish assemblages and species distribution in Korean rivers (Lee et al., 2011b; NIBR, 2011). Increasing water temperature due to global warming is projected to affect water quality and to exacerbate many forms of water pollution. Global warming is tightly linked with changes in hydrological cycle, which induces variability in precipitation pattern and river discharge (Harvey, 1987; Poff et al., 2001; Mauget, 2003; Bates et al., 2008). Such changes could affect the distribution and abundance of freshwater fish altogether (Ficke et al., 2007). To better understand the response of fish community structure to global warming it may help to understand how the change in the abundance of one species affect that of another species in the assemblage through predation or competition (Bayley and Li, 1992; Taniguchi et al., 1998; Rahel, 2002).

\section{Conclusions}

The results of this study indicate that the negative effect of global warming on the changes in biodiversity of endemic riverine fish would be apparent within next several decades by decreasing the thermal habitat suitability of the species in the major river basins in the Southern Korean Peninsula. It was expected that the reduction in suitable thermal habitats of the fish due to global warming might be observed within 2060s, although increasing water temperature is not currently the most important driver of biodiversity change (CCSP, 2008) in the major river ecosystems in Korea. Anthropogenic factors, including channel modification, water quality degradation and dam construction, may play a greater role in reducing suitable habitats of freshwater fish than global warming before 2060s. The results imply that the conservation efforts for Korean endemic freshwater fish need to incorporate the difference in the projected thermal regime among the major basins based on the climate change scenario, reflecting the spatial heterogeneity in the degree of warming. The changes in thermal habitat suitability of endemic riverine fish were variable among basins according to the level of basin-specific temperature 
elevation. The relationship between altitude and the change in thermal habitat suitability also suggests that it is required to establish the strategies for biodiversity conservation of endemic freshwater fish in each basin specifically. Based on the basin-specific projections of distributional change, it might be possible to identify the species (or population) requiring priority conservation and recovery efforts (Chu et al., 2005) not only for the protection of endangered species but also for all endemic riverine fishes under the effect of global warming.

Acknowledgements. This study was supported by the National Institute of Environmental Research, Ministry of Environment (Korea).

\section{References}

Bae M.-J., Kwon Y., Hwang S.-J., Chon T.-S., Yang H.-J., Kwak I.-S., Park J.-H., Ham S.-A. and Park Y.-S., 2011. Relationship between three major stream assemblages and their environmental factors in multiple spatial scales. Ann. Limnol. - Int. J. Lim., 47, S91-S105.

Bates B.C., Kundzewicz Z.W., Wu S. and Palutikof J.P. (eds.), 2008. Climate Change and Water. Technical Paper of the Intergovernmental Panel on Climate Change, IPCC Sectetariat, Geneva, 200 p.

Bayley P.B. and Li H.W., 1992. Riverine fishes. In: Calow P. and Petts G.E. (eds.), The Rivers Handbook: Hydrological and Ecological Principles, Vol. 1: Blackwell Scientific Publications, Oxford, 251-281.

Buisson L., Grenouillet G., Villéger S., Canal J. and Laffaille P., 2013. Toward a loss of functional diversity in stream fish assemblages under climate change. Glob. Change Biol., 19, $387-400$.

Caissie D., 2006. The thermal regime of rivers: a review. Freshw. Biol., 51, 1389-1406.

CCSP, 2008. The effects of climate change on agriculture, land resources, water resources, and biodiversity in the United States. A report by the U.S. Climate Change Science Program and the subcommittee on global change research. U.S. Environmental Protection Agency, Washington, DC, 362 p.

Chu C., Mandrak N.E. and Minns C.K., 2005. Potential impacts of climate change on the distributions of several common and rare freshwater fishes in Canada. Divers. Distrib., 11, 299-310.

Cohen S., Miller K., Duncan K., Gregorich E., Groffiman P., Kovacs P., Magaňa V., McKnight D., Mills E. and Schimel D., 2001. North America. In: McCarthy J.J., Canziani O.F., Leary N.A., Dokken D.J. and White K.S. (eds.), Climate Change 2001: Impact, Adaptation and Vulnerability. Contribution of Working Group II to the third Assessment Report of the Intergovernmental Panel on Climate Change, Cambridge University Press, Cambridge, 735-800.

Doi H., 2008. Delayed phenological timing of dragonfly emergence in Japan over five decades. Biol. Lett., 4, 388-391.

Domisch S., Araújo M.B., Bonada N., Pauls S.U., Jähnig S.C. and Haase P., 2013. Modelling distribution in European stream macroinvertebrates under future climates. Glob. Change Biol., 19, 752-762.
Ducharne A., 2008. Importance of stream temperature to climate change impact on water quality. Hydrol. Earth Syst. Sci., 12, 797-810.

Eaton J.G. and Scheller M., 1996. Effects of climate warming on fish thermal habitat in streams of the United States. Limnol. Oceanogr., 41, 1109-1115.

ESRI, 2004. ArcGIS Software. Environmental Systems Research Institute, Redlands.

Ficke A., Myrick C. and Hansen L., 2007. Potential impacts of global climate change on freshwater fisheries. Rev. Fish Biol. Fisher., 17, 581-613.

Field C.B., Mortsch L.D., Brklacich M., Forbes D.L., Kovacs P., Patz J.A., Running S.W. and Scott M.J., 2007. North America. In: Parry M.L., Canziani O.F., Palutikof J.P., van der Linden P.J. and Hanson C.E. (eds.), Climate Change 2007: Impacts, Adaptation and Vulnerability, Contribution of Working Group II to the Fourth Assessment Report of the Intergovernmental Panel on Climate Change, Cambridge University Press, Cambridge, 17-652.

Grell G.A., Dudhia J. and Stauffer D.R., 1994. A Description of the Fifth-Generation Penn State/NCAR Mesoscale Model (MM5), NCAR Technical Note NCAR/TN-398 + STR, Mesoscale and Microscale Meteorological Division, National Center for Atmospheric Research, Boulder.

Harvey B.C., 1987. Susceptibility of young-of-the year fishes to downstream displacement by flooding. Trans. Am. Fisher. Soc., 116, 851-855.

Heino J., Virkkala R. and Toivonen H., 2009. Climate change and freshwater biodiversity: detected patterns, future trends and adaptations in northern regions. Biol. Rev., 84, 39-54.

Hwang S.-J., Kim N.-Y., Yoon S., Kim B.-H., Park M.H., You K.-A., Lee H.Y., Kim H.S., Kim Y.J. and Lee J., 2011. Distribution of benthic diatoms in Korean rivers and streams in relation to environmental variables. Ann. Limnol. - Int. J. Lim., 47, S15-S33.

IBM, 2011. IBM SPSS Statistics 20.0.0, IBM Corporation, Somers.

IPCC, 2007. Climate change 2007: impacts, adaptation and vulnerability. In: Parry M.L., Canziani O.F., Palutikof J.P., van der Linden P.J. and Hanson C.E. (eds.), Contribution of Working Group II to the Fourth Assessment Report of the Intergovernmental Panel on Climate Change, Cambridge University Press, Cambridge, 976 p.

Juggins S., 2007. C2 version 1.5 user guide. Software for Ecological and Palaeoecological Data Analysis and Visualization, Newcastle University, Newcastle upon Tyne.

Karl T.R., Melillo J.M. and Peterson T.C. (eds.), 2009. Ecosystems. In: Global Climate Change Impacts in the United States, Cambridge University Press, New York, 79-88.

Kim D.S., 2000. Korean vegetation types using NOAA/AVHRR data. J. Korean Geogr. Soc., 35, 39-51 (in Korean with English abstarct).

Kim I.S. and Park J.Y., 2002. Freshwater Fish of Korea, KyoHak Publishing, Seoul, 465 p. (in Korean).

Kojiri T., Hamaguchi T. and Ode M., 2008. Assessment of global warming impacts on water resources and ecology of a river basin in Japan. J. Hydro-Environ. Res., 1, 164-175.

Kong W.-S., 2004. Species composition and distribution of native Korean conifers. J. Korean Geogr. Soc., 39, 528-543 (in Korean with English abstract). 
Kwon Y.-S., Li F., Chung N., Bae M.-J., Hwang S.-J., Byoen M.-S., Park S.-J. and Park Y.-S., 2012. Response of fish communities to various environmental variables across multiple spatial scales. Int. J. Environ. Res. Public Health, 9(10), 3629-3653.

Langan S.J., Johnston L., Donaghy M.J., Youngson A.F., Hay D.W. and Soulsby C., 2001. Variation in river water temperatures in an upland stream over a 30 -year period. Sci. Total Environ., 265, 195-207.

Lee J.-H., Han J.-H., Kumar H.K., Choi J.-K., Byeon H.K., Choi J., Kim J.-K., Jang M.-H., Park H.-K. and An K.-G., 2011a. National-level integrative ecological health assessments based on the index of biological integrity, water quality, and qualitative habitat evaluation index, in Korean rivers. Ann. Limnol. - Int. J. Lim., 47, S73-S89.

Lee S.-W., Hwang S.-J., Lee J.-K., Jung D.-I., Park Y.-J. and Kim J.-T., 2011b. Overview and application of the National Aquatic Ecological Monitoring Program (NAEMP) in Korea. Ann. Limnol. - Int. J. Lim., 47, S3-S14.

Legutke S. and Voss R., 1999. The Hamburg Atmosphere-Ocean Coupled Circulation Model ECHO-G, German Climate Computer Center (DKRZ), Hamburg, 62 p.

Lehtonen H., 1996. Potential effects of global warming on northern European freshwater fish and fisheries. Fisher. Manag. Ecol., 3, 59-71.

Li F., Cai Q., Jiang W. and Qu X., 2012a. Macroinvertebrate relationships with water temperature and water flow in subtropical monsoon streams of Central China: implications for climate change. Fund. Appl. Limnol./Arch. Hydrobiol., 180, 221-231.

Li F., Cai Q., Jiang W. and Qu X., 2012b. The response of benthic macroinvertebrate communities to climate change: evidence from subtropical mountain streams in Central China. Int. Rev. Hydrobiol., 97, 200-214.

Li F., Chung N., Bae M.-J., Kwon Y.-S., Kwon T.-S. and Park Y.-S., 2013. Temperature change and macroinvertebrate biodiversity: assessments of organism vulnerability and potential distributions. Clim. Change, 119, 421-434.

Li F., Kwon Y.-S., Bae M.-J., Chung N., Kwon T.-S. and Park Y.-S., 2014. Potential impacts of global warming on the diversity and distribution of stream insects in South Korea. Conserv. Biol., 28, 498-508.

Li F., Tierno de Figueroa J.M., Lek S. and Park Y.-S., 2015. Continental drift and climate change drive instability in insect assemblages. Sci. Rep., 5, 11343.

Magnuson J.J., Crowder L.B. and Medvick P.A., 1979. Temperature as an ecological resource. Am. Zool., 19, 331-343.

Mauget S.A., 2003. Multidecadal regime shifts in US streamflow, precipitation, and temperatures at the end of the twentieth century. J. Clim., 16, 3905-3916.

MOE/NIER, 2008. The Survey and Evaluation of Aquatic Ecosystem Health in Korea, The Ministry of Environment/ National Institute of Environmental Research, Incheon, 337 p (in Korean with English summaries).

MOE/NIER, 2009. A Photobook and Guide to Freshwater Fishes in Rivers of Korea (I), The Ministry of Environment/ National Institute of Environmental Research, Incheon, 259 p. (in Korean).

Mohseni O. and Stefan H.G., 1999. Stream temperature/ air temperature relationship: a physical interpretation. J. Hydrol., 218, 128-141.
Mohseni O., Erickson T.R. and Stefan H.G., 1999. Sensitivity of stream temperatures in the United States to air temperatures projected under a global warming scenario. Water Resour. Res., 35, 3723-3733.

Mohseni O., Stefan H.G. and Eaton J.G., 2003. Global warming and potential changes in fish habitat in U.S. streams. Clim. Change, 59, 389-409.

Moore R.D., 2006. Stream temperature patterns in British Columbia, Canada, based on routine spot measurements. Can. Water Resour. J., 31, 41-56.

Morrill J.C., Bales R.C. and Conklin M.H., 2005. Estimating stream temperature from air temperature: implications for future water quality. J. Environ. Eng., 131, 139-146.

Murdoch P.S., Baron J.S. and Miller T.L., 2000. Potential effects of climate change on surface-water quality in North America. J. Am. Water Resour. Assoc., 36, 347-366.

Nakicenovic N., Alcamo J., Davis G., de Vries B., Fenhann J., Gaffin S., Gregory K., Grubler A., Jung T.Y., Kram T., La Rovere E.L., Michaelis L., Mori S., Morita T., Pepper W., Pitcher H.M., Price L., Riahi K., Roehrl A., Rogner H.-H., Sankovski A., Schlesinger M., Shukla P., Smith S.J., Swart R., van Rooijen S., Victor N. and Dadi Z., 2000. Special Report on Emissions Scenarios: a Special Report of Working Group III of the Intergovernmental Panel on Climate Change, Cambridge University Press, New York, $570 \mathrm{p}$.

NIBR, 2011. Red Data Book of Endangered Fishes in Korea, National Institute of Biological Resources, Incheon, 202 p (in Korean with English summary)

O'Neal K., 2002. Effects of Global Warming on Trout and Salmon in U.S. Streams, Defenders of Wildlife, Washington, DC, $46 \mathrm{p}$.

Parmesan C., 2006. Ecological and evolutionary responses to recent climate change. Annu. Rev. Ecol. Evol. Syst., 37, 637-669.

Parmesan C., Duarte C., Poloczanska E., Richardson A.J. and Singer M.C., 2011. Overstretching attribution. Nat. Clim. Change, 1, 2-4.

Pereira H.M., Leadley P.W., Proença V., Alkemade R., Scharlemann J.P.W., Fernandez-Manjarrés J.F., Araújo M.B., Balvanera P., Biggs R., Cheung W.W.L., Chini L., Cooper H.D., Gilman E.L., Guénette S., Hurtt G.C., Huntington H.P., Mace G.M., Oberdorff T., Revenga C., Rodrigues P., Scholes R.J., Sumaila U.R. and Walpole M., 2010. Scenarios for global biodiversity in the 21 st century. Science, 330, 1496-1501.

Pereira H.M., Navarro L.M. and Martins I.S., 2012. Global biodiversity change: the bad, the good, and the unknown. Annu. Rev. Environ. Resour., 37, 25-50.

Poff N.L., 1997. Landscape filters and species traits: towards mechanistic understanding and prediction in stream ecology. J. N. Am. Benthol. Soc., 16, 391-409.

Poff N.L., Angermeier P.L., Cooper S.D., Lake P.S., Fausch K.D., Winemiller K.O., Mertes L.A.K., Oswood M.W., Reynolds J. and Rahel F.J., 2001. Fish diversity in streams and rivers. In: Chapin F.S.I., Sala O.E. and Huber-Sannwald E. (eds.), Global Biodiversity in a Changing Environment: Scenarios for the 21st Century, Springer, New York, 351-368.

Rahel F.J., 2002. Using current biogeographic limits to predict fish distributions following climate change. In: McGinn N.A. (ed.), Fisheries in a Changing Climate, American Fisheries Society, Bethesda, 99-109. 
Rahel F.J., Keleher C.J. and Anderson J.L., 1996. Potential habitat loss and population fragmentation for cold water fish in the North Platte River drainage of the Rocky Mountains: response to climate change. Limnol. Oceanogr., $41,1116-1123$.

Ricciardi A. and Rasmussen J.B., 1999. Extinction rates of North American freshwater fauna. Conserv. Biol., 13, 1220 1222.

Rieman B.E., Isaak D., Adams S., Horan D., Nagel D., Luce C. and Myers D., 2007. Anticipated climate warming effects on bull trout habitats and populations across the interior Columbia River basin. Trans. Am. Fish. Soc., 136, 1552-1565.

Sala O.E., Chapin F.S., Armesto J.J., Berlow E., Bloomfield J., Dirzo R., Huber-Sanwald E., Huenneke L.F., Jackson R.B., Kinzig A., Leemans R., Lodge D.M., Mooney H.A., Oesterheld M., Poff N.L., Sykes M.T., Walker B.H., Walker M. and Wall D.H., 2000. Global biodiversity scenarios for the year 2100. Science, 287, 1770-1774.

Scott M.C., Helfman G.S., McTammany M.E., Benfield E.F. and Bolstad P.V., 2007. Multiscale infuences on physical and chemical stream conditions across Blue Ridge landscapes. J. Am. Water Resour. As., 38, 1379-1392.

Snelder T.H. and Biggs B.J.F., 2002. Multiscale river environment classification for water resources management. J. Am. Water Resour. Assoc., 38, 1225-1239.

Sutherland W.J., Freckleton R.P., Godfray H.C.J., Beissinger S.R., Benton T., Cameron D.D., Carmel Y., Coomes D.A., Coulson T., Emmerson M.C., Hails R.S., Hays G.C., Hodgson D.J., Hutchings M.J., Johnson D., Jones J.P.G., Keeling M.J., Kokko H., Kunion W.E., Lambin X., Lewis O.T., Malhi Y., Mieszkowska N., MilnerGulland E.J., Norris K., Phillimore A.B., Purves D.W., Reid J.M., Reuman D.C., Thompson K., Travis J.M.J., Turnbull L.A., Wardle D.A. and Wiegand T., 2013. Identification of 100 fundamental ecological questions. J. Ecol., 101, 58-67.
Taniguchi Y., Rahel F.J., Novinger D.C. and Gerow K.G., 1998. Temperature mediation of competitive interactions among three fish species that replace each other along longitudinal stream gradients. Can. J. Fish. Aquat. Sci., 55, 1894-1901.

ter Braak C.J.F. and Juggins S., 1993. Weighted averaging partial least squares regression (W-PLS): an improved method for reconstructing environmental variables from species assemblages. Hydrobiologia, 269-270, 485-502.

ter Braak C.J.F. and van Dam H., 1989. Inferring $\mathrm{pH}$ from diatoms: a comparison of old and new calibration methods. Hydrobiologia, 178, 209-223.

Vörösmarty C.J., McIntyre P.B., Gessner M.O., Dudgeon D., Prusevich A., Green P., Glidden S., Bunn S.E., Sullivan C.A., Liermann C.R. and Davies P.M., 2010. Global threats to human water security and river biodiversity. Nature, 467, 555-561.

Walling D.E. and Webb B.W., 1994. Water quality: I. Physical characteristics. In: Calow P. and Petts G.E. (eds.), The Rivers Handbook: Hydrological and Ecological Principles, Vol. 2: Blackwell Scientific Publications, Oxford, 48-72.

Webb B.W., Hannah D.M., Moore R.D., Brown L.E. and Nobilis F., 2008. Recent advances in stream and river temperature research. Hydrol. Process., 22, 902-918.

Welch E.B., Jacoby J.M. and Lindell T., 2004. Fish. In: Pollutant Effects in Freshwater (3rd edn), Spon Press, New York, 353-399.

Xenopoulos M.A., Lodge D.M., Alcamo J., Märker M., Schulze K., van Vuuren D.P., 2005. Scenarios of freshwater fish extinctions from climate change and water withdrawal. Glob. Change Biol., 11, 1557-1564.

Yoon J.-D., Kim J.-H., Byeon M.-S., Yang H.-J., Park J.-Y., Shim J.-H., Song H.-B., Yang H. and Jang M.-H., 2011. Distribution patterns of fish communities with respect to environmental gradients in Korean streams. Ann. Limnol. Int. J. Lim., 47, S63-S71. 